DedikasiMU (Journal of Community Service)

Volume 2, Nomor 1, Maret 2020

\title{
LITERASI KEUANGAN MENABUNG SEJAK DINI DAN PENDAMPINGAN \\ PENGELOLAAN KEUANGAN BERBASIS PEMBUKUAN SEDERHANA PADA \\ BANK SAMPAH DESA BRANGKAL, KECAMATAN BALONGPANGGANG, KABUPATEN GRESIK
}

\author{
Anwar Hariyono', Andi Rahmad Rahim², Nikmatur Rochmah ${ }^{3}$, Nur Azizah ${ }^{4}$, Rahma Firdausi ${ }^{5}$, \\ Zulfiqar Alif Taufiqurrahman ${ }^{6}$ \\ ${ }^{1}$ Dosen Program Studi Akuntansi, Universitas Muhammadiyah Gresik \\ ${ }^{2}$ Dosen Program Studi Akuakultur, Universitas Muhammadiyah Gresik \\ 3,4,5,6 Mahasiswa Program Studi Akuntansi, Universitas Muhammadiyah Gresik \\ Email: Nabilamuzayyanah98@gmail.com
}

\begin{abstract}
ABSTRAK
Kegiatan Kuliah Kerja Nyata (KKN) Universitas Muhammadiyah Gresik tahun 2019 dilaksanakan mulai tanggal 02 Agustus 2019 sampai dengan tanggal 20 Oktober 2019. Salah satu tempat pelaksanaan kegiatan KKN adalah di Desa Brangkal Dusun Kedung Pangsing Kecamatan Balongpanggang Kabupaten Gresik, yang diikuti oleh program studi Akuntansi dan 5 (lima) program studi lain. Mahasiswa program studi Akuntansi melaksanakan program kerja unggulan yakni pendampingan dan pembuatan format pembukuan sederhana pada bank sampah Desa Brangkal tepatnya di Dusun Kedung Pangsing dan juga literasi keuangan dengan menabung sejak dini . Kegiatan pendampingan pembukuan sederhana pada bank sampah Dusun Kedung Pangsing bertujuan untuk membantu dan membimbing pengurus bank sampah untuk melakukan pembukuan sederhana dalam mengelola keuangan bank sampah serta pengurus diberikan pendampingan untuk dapat menyajikan laporan keuangan yang baik dan benar sesuai standar akuntansi yang berlaku. Kegiatan ini dilakukan dengan memberikan gambaran dan tata cara pengelolaan keuangan dan pembukuan akuntansi dasar di Dusun Kedung Pangsing. Fun education menabung sejak dini bertujuan untuk memberikan penjelasan, motivasi dan menanamkan kesadaran tentang pentingnya menabung, memanfaatkan sampah botol bekas menjadi celengan serta mengasah kreativitas anak anak dalam kreasi botol celengan. Kegiatan yang telah dilaksanakan oleh mahasiswa program studi Akuntansi berjalan lancar dan sukses sesuai apa yang sudah direncanakan. Semua pihak mengharapkan agar kegiatan ini dapat membantu memperbaiki Desa Brangkal menjadi lebih baik lagi.
\end{abstract}

Keywords: Akuntansi, Pembukuan, Bank Sampah, Celengan, Menabung, Desa Brangkal. 


\section{PENDAHULUAN}

\section{A. Latar Belakang}

Kuliah Kerja Nyata (KKN) merupakan bentuk pengabdian nyata seorang mahasiswa kepada masyarakat yang sebenarnya setelah mendapatkan materi perkuliahan yang senantiasanya dapat berguna di dalam lingkungan masyarakat itu sendiri. Dalam kegiatan pengabdiannya pada masyarakat, mahasiswa memberikan pengalaman ilmu pengetahuan, teknologi, seni, dan agama untuk memberikan pengarahan agar dapat memecahkan masalah dan menanggulanginya secara tepat. Melalui KKN ini mahasiswa dapat secara langsung maupun tidak langsung membantu pembangunan dan kemajuan di masyarakat.

Desa Brangkal merupakan desa yang terpilah menjadi salah satu lokasi KKN tepatnya berada di Kecamatan Balongpanggang Kabupaten Gresik. Desa Brangkal merupakan desa yang terletak di area penduduk yang padat. Mata pencaharian penduduk mayoritas adalah sebagai petani baik di lahan sendiri maupun sebagai petani penggarap di lahan milik orang lain (petani kecil, sisanya adalah industry rumah tangga. Ibu-ibu PKK di Desa Brangkal tergolong aktif dalam menjalankan kegiatan, sehingga aktifitas yang dilakukan oleh ibu-ibu menjadikan Desa Brangkal semakin maju.

Berdasarkan UU No. 18 tahun 2008 tentang pengelolaan sampah menyebutkan, sampah adalah sisa ataupun buangan yang merupakan hasil buatan manusia dalam kegiatan sehari-hari ataupun hasil dari proses alam yang berbentuk padat maupun semi padat berupa zat organik maupun anorganik yang bersifat dapat terurai maupun tidak dapat terurai yang sudah tidak digunakan lagi. Bank sampah merupakan suatu tempat yang digunakan untuk mengumpulkan sampah yang sudah dipilah-pilah yakni sampah yang berbentuk anorganik yang disetorkan ke tempat pengepul sampah. Bank sampah merupakan suatu sistem yang dikelola seperti pengelolaan perbankan yang dilakukan oleh petugas yang bertindak sebagai pengurus bank sampah secara sukarelawan. Penyetor merupakan warga yang mengumpulkan dan menyetorkan sampah yang telah dikumpulkan dan sudah dipilah ke bank sampah.

Bank sampah Kedung Pangsing ini hanya melakukan penyetoran saja ke Pengepul tanpa melakukan pengolahan kembali sampah yang dikumpulkan oleh masyarakat. Sampah yang biasa terkumpul diantaranya sampah plastik, buku, karak, kaleng, besi, almini dll. Pengepul biasanya mengambil sampah setiap satu bulan sekali di 
akhir bulan. Pengepul membeli sampah itu dengan laba sebesar Rp 100,- per kg. Keuntungan dari penjualan sampah-sampah nantinya untuk keperluan masyarakat.

Pengurus bank sampah Desa Brangkal belum memahami tentang pembukuan akuntansi dasar. Maka dari itu, mahasiswa KKN program studi Akuntansi menyelenggarakan pendampingan pembukuan yang nantinya khususnya pada Pengurus bank sampah Desa Brangkal diharapkan dapat mengelola keuangannya dengan baik dan mampu mengaplikasikan pembukuan akuntansi yang baik dan benar sesuai standar akuntansi yang berlaku.

Menabung bisa diartikan dengan menyisihkan sebagian uang saku yang dimiliki untuk disimpan dalam jangka waktu tertentu.

Akan tetapi yang menjadi permasalahan yaitu tabungan tersebut bukan berisi penyisihan uang saku siswa - siswi, melainkan uang yang sudah direntankan untuk ditabung bagi orang tua. Dalam kondisi ini, bisa dikatakan bahwa yang menabung bukan lgi anak-anak tetapi orang tua mereka, anak-anak hanya menjadi perantara untuk menyalurkan uang tabungan orang tua mereka ke sekolahan.

Dan kondisi ini tidak semua orang sadari sehingga pelaksanaan kegiatan menabung di tabungan tersebut membuat anak- anak merasa menabung itu ternyata seperti ini, meminta uang kepada orang tua lalu dimasukkan ke dalam buku tabungan setelah itu disetorkan ke bapak ibu guru, dicatat dan nanti buku tabungannya dikembalikan dan diisi lagi.

Kebiasaan orang tua yaitu memberi dan memisahkan antara uang saku yang diberikan kepada anaknya dengan uang tabungan untuk sekolah, hal ini tentunya belum bisa dikatakan secara sepenuhnya bahwa anak - anak sudah diajari menabung sejak usia dini dan akan sangat berbahaya jika anak-anak tidak diberikan penjelasan yang benar mengenai apa itu menabung dan pentingnya menabung.

\section{B. Rumusan Masalah}

Berdasarkan latar belakang di atas, maka dapat dikemukakan rumusan masalah sebagai berikut:

1. Bagaimana prosedur pembukuan bank sampah yang dilakukan oleh pengurus bank sampah Desa Brangkal?

2. Bagaimana penerapan literasi keuangan yang dilakukan oleh anak-anak warga Desa Brangkal? 


\section{Tujuan}

Berdasarkan identifikasi dan perumusan masalah disusun tujuan penelitian sebagai berikut:

1. Untuk memberikan pengetahuan dasar kepada pengurus mengenai pembukuan sederhana bank sampah Desa Brangkal.

2. Untuk menanamkan kesadaran pada anak-anak bahwa menabung sejak usia dini itu perlu dan mengasah kreatifitas anak dengan menerapkan membuat celengan dari botol bekas.

\section{METODE}

Metode Pelaksanaan Kegiatan "Pendampingan Pengelolaan Keuangan Pembukuan Sederhana pada Bank Sampah"meliputi;

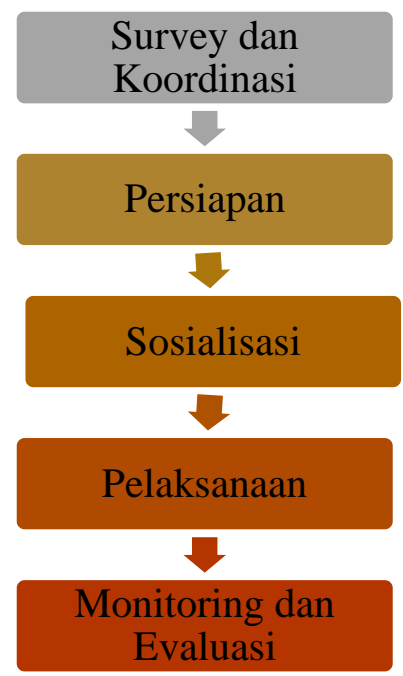

Gambar 1. Tahapan pelaksanaan program kerja

\section{A. Survey dan Koordinasi (Persiapan)}

Persiapan dapat dilakukan dengan cara pengumpulan informasi awal tentang bank sampah yang ada di Desa Brangkal Dusun Kedung Pangsing, dan mengadakan pertemuan dengan pihak yang terkait untuk mencari informasi yang lebih tentang kegiatan Bank Sampah tersebut. 


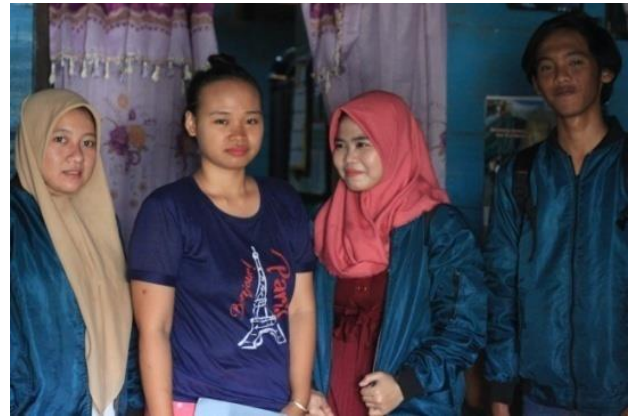

Gambar 2. Pertemuan dengan Pengurus Inti Bank Sampah

\section{B. Sosialisasi}

Menyampaikan maksud dan tujuan kegiatan dalam bentuk pendampingan pengelolaan keuangan bank sampah di Desa Brangkal, Dusun Kedung Pangsing, Balongpanggang Gresik. Kegiatan tersebut ditujukan kepada pengurus Bank Sampah.

Pengurus bank sampah diberikan pengetahuan mengenai pembukuan dalam akuntansi dengan cara mempresentasikan cara mengisi akun-akun yang biasa muncul dalam pembukuan.

Pengimplementasiannya dengan cara memberikan buku rincian penjualan atau penyetoran sampah, buku induk tabungan, laporan realisasi penjulan, dan laporan kas kepada pengurus bank sampah sehingga bisa langsung dipraktekkan.

Dalam proses pendampingan, pengurus bank sampah diberikan kesempatan untuk mengajukan pertanyaan-pertanyaan mengenai kesulitan yang dihadapi. Beberapa kesulitan yang dialami adalah memahami alur pencatatan pembukuan dari transaksi sampai laporan realisasi penjualan selanjutnya adalah laporan kas.

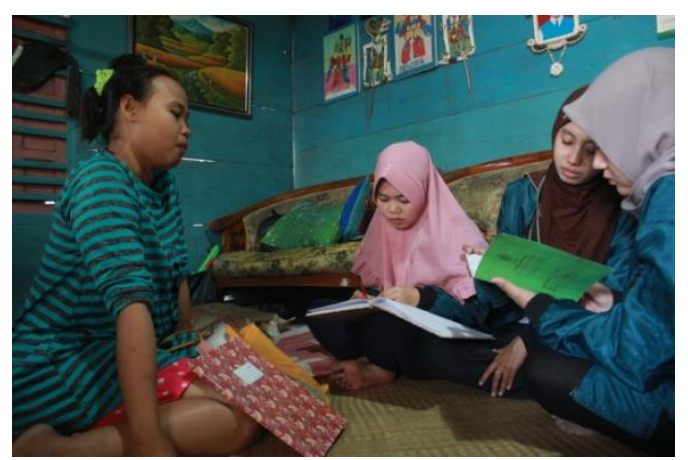

Gambar 3. Sosialisasi Mengenai Pembukuan Bank Sampah 


\section{Pelaksanaan}

Metode pelaksanaan :

1. Mahasiswa menyiapkan sarana prasarana dan peralatan yang digunakan dalam pendampingan pembukuan sederhana bank sampah.

2. Mahasiswa membantu menimbang Sampah yang dikumpulkan oleh warga

3. Mahasiswa melakukan pelatihan cara pembukuan akuntansi sederhana mulai dari tahap pencatatan transaksi sampai laporan kas.

4. Pengurus Bank Sampah mempraktikkan pembukuan sederhana yang telah diajarkan.

5. Mengevaluasi hasil pendampingan pembukuan sederhana.

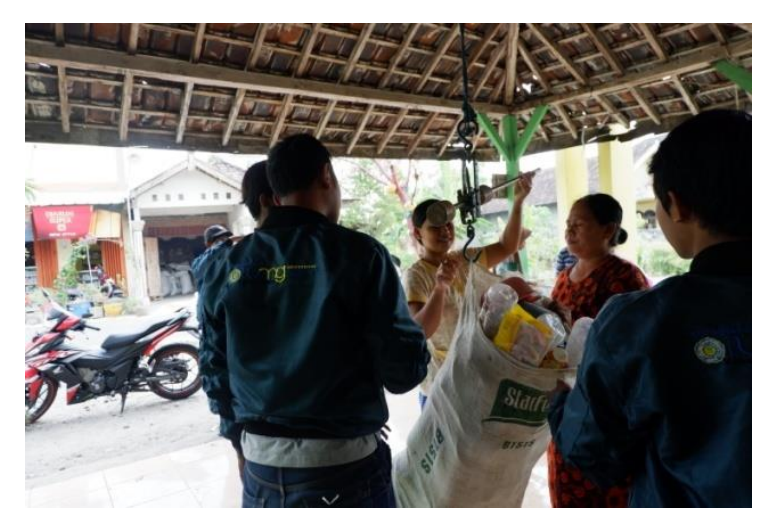

Gambar 4. Proses Penimbangan Sampah yang Dikumpulkan Warga

\section{Teknik Pelaksanaan}

Pelaksanaan kegiatan Pengabdian Pada Masyarakat ini dilakukan dengan menggunakan metode, tutorial, dan diskusi. Adapun sistematika pelaksanaan kegiatan pengabdian ini adalah sebagai berikut:

Langkah 1 (Metode Tutorial):

Mahasiswa memberikan contoh pencatatan pembukuan keuangan sederhana yang dimulai dari pencatatan transaksi sampai dengan menyusun laporan kas yang benar dan mudah dipahami oleh Pengurus Inti Bank Sampah Kedung Pangsing.

Langkah 2 (Metode Diskusi):

Mahasiswa memberikan materi tentang pembukuan sederhana Bank Sampah kepada pengurus inti Bank Sampah. Metode ini dimulai dengan penjelasan dari mahasiswa yang dilanjut dengan sesi tanya jawab dan mendiskusikan kendala yang dialami antara Pengurus Inti dan Mahasiswa. 


\section{E. Monitoring dan Evaluasi}

Beberapa kendala mungkin muncul saat penerapan pencatatan bank sampah. Monitoring dan evaluasi dilaksanakan untuk mengetahui perkembangan pelaksanaan kegiatan, dan menilai kesesuaian kegiatan yang telah dilaksanakan dengan perencanaan. Hasil yang dicapai yakni respon baik para pengurus bank sampah dimana mereka mau.

\section{F. Sosialisasi}

Sosialisasi dilakukan pada hari sabtu siang jam 14.00 di Rumah singgah Desa Brangkal. Sosialisasi berisi penjelasan tentang pentingnya menabung sejak usia dini, mengajak anak- anak Desa Brangkal untuk gemar menabung dan membiasakan hidup hemat tidak boros, apalagi melihat kondisi dimana pemberian uang saku oleh orang tua kepada Anak- anak yang dinilai sangat cukup dan kondisi dimana sebagian besar siswasiswi lebih suka menghabiskan uangsaku dalam sehari saat bersekolah.

Selain mengajak anak- anak untuk gemar menabung, dalam sosialisasi juga memberikan motivasi dan pengetahuan bahwa botol bekas juga bisa dimanfaatkan sebagai celengan, jadi dapat mendaur ulang sampah dan juga tidak perlu membeli celengan.

Selain itu, untuk menambah motivasi dan mengasah kreativitas siswa-siswi, botol bekas tidak hanya di lubangi saja, tetapi juga diberi pelapis Kain flannel sesuai dengan kreativitas masing-masing dan akan diberi nama untuk tiap-tiap kepemilikan celengan. Setelah sosialisasi dilakukan, siswa-siswi dihimbau agar membawa botol bekas dari rumah.

\section{HASIL DAN PEMBAHASAN}

Hasil program kerja, pembukuan bank sampah Desa Brangkal yang dilakukan oleh program studi Akuntansi kelompok 3 adalah :

Survey kami laksanakan pada hari Minggu, 25 Agustus 2019. Kegiatan ini dilaksanakan dengan cara mengadakan pertemuan yang melibatkan pengurus inti dari bank sampah. Pertemuan tersebut dilakukan di rumah pengurus inti bank sampah yang betujuan untuk mendiskusikan tentang kendala yang dihadapi oleh pengurus bank sampah dalam proses pencatatan pembukuan Bank Sampah.

Kegiatan selanjutnya dilakukan dengan mengikuti kegiatan Bank Sampah setiap akhir bulan. Seperti melakukan penarikan sampah dari masyarakat setiap hari Minggu, lalu menimbang sampah yang dikumpulkan tersebut dan pencatatannya. Sampah 


\section{DedikasiMU (Journal of Community Service)}

Volume 2, Nomor 1, Maret 2020

yang telah dikumpulkan oleh masyarakat selanjutnya dijual kepada pengepul yang telah bekerja sama dengan Bank Sampah Kedung Pangsing.

15 September 2019 dilakukan pertemuan dengan pengurus inti bank sampah untuk menyampaikan hasil format pencatatan pada buku Bank Sampah yang akan dibuat oleh Mahasiswa. Hasil dari pertemuan tersebut berupa kesepakatan format buku Bank Sampah yang sesuai dengan aturan akuntansi.

Evaluasi dari kegiatan yang telah dilaksanakan terdapat beberapa hambatan yaitu kurangnya pengetahuan ilmu akuntansi dari beberapa masyarakat dalam sosialisasi pembukuan Bank Sampah.

Akan Tetapi program kerja ini mendapat respon positif baik untuk pengurus inti bank sampah, dimana mereka mau mencoba untuk segera mengaplikasikannya dalam pembukuan bank sampah. Program ini juga mendapatkan respon positif dari masyarakat, terbukti masyarakat sangat antusias atas pelaksanaan kegiatan tersebut. Adapun untuk tindak lanjut dari kegiatan utama ini adalah diharapkan ke depannya mereka tetap konsisten dalam menjalankan pembukuan ini sehingga bisa bermanfaat bagi masyarakat Desa Brangkal.

Tahapan pelaksanaan program kerja merupakan hal yang sangat penting dalam menentukan keberhasilan dari program kerja Literasi Keuangan Menabung termasuk sosialisasi kepada anak-anak untuk mengajak, memotivasi dan mengasah kreativitas anak- anak Desa Brangkal, persiapan dalam pembuatan celengan dan tentunya tindak lanjut dari sosialisasi tersebut dengan membiasakan anak-anak untuk gemar mengisi celengan mereka.

Hasil dan pembahasan dari program kerja yang dilakukan oleh program studi Akuntansi kelompok 3 dengan melakukan sosialisasi dan pembuatan celengan ini dilakukan di Desa Brangkal.

Berdasarkan survey yang dilakukan tim KKN kelompok 3 prodi Akuntansi di Desa Brangkal, kebanyakan siswa-siswinya tidak mempunyai celengan di rumah, terlalu bersikap konsumtif bahkan mengahabiskan uang saku pemberian orang tua dalam sehari saat bersekolah tanpa menyisihkannya untuk menabung di rumah. Tetapi ada juga yang sudah mempunyai celengan di rumah tetapi bukan dari pemanfaatan botol bekas melainkan didapat dari membeli celengan dan kebanyakan juga celengan dirumah diambili dan dibuka meskipun baru memasukkan uang ke dalam celengan karena tidak ada yang mengawasi. 
Setelah adanya program kerja literasi keuangan menabung sejak dini, orang tua dapat terbantu dalam mendidik anak untuk memotivasi dan membiasakan menabung sejak dini, mengurangi sikap konsumtif bagi anak, mengajari anak-anak tentang pengetahuan bahwa sampah bisa di daur ulang bahkan bisa menjadi celengan mereka dan mengasah kreativitas anak-anak dalam hal berkreasi.

Selain itu tanggapan yang positif juga diberikan oleh Bapak Kepala Desa Brangkal, program "Literasi Keuangan Menabung Sejak Dini” sangat mendidik anakanak akan tetapi kurang lamanya waktu yang menjadi hambatan, karena KKN dilaksanakan dalam 36 hari jangka waktu 3 bulan pada hari jumat, sabtu dan minggu.

\section{KESIMPULAN DAN SARAN}

\section{A. Kesimpulan}

1. Bank Sampah di Dusun Kedung Pangsing Desa Brangkal dikelola oleh pengurus inti yang bernama Mbak Indah. Pembinaan pembukuan bank sampah dilakukan oleh mahasiswa program studi akuntansi tim KKN Tematik 3 Desa Brangkal, dapat mencapai tujuan yaitu terwujudnya sistem pembukuan yang sesuai dengan aturan akuntansi sehingga memudahkan pengurus dalam melakukan pencatatan transaksi sampai pembuatan laporan kas keuangan bank sampah.

2. Berkurangnya sikap konsumtif siswa-siswi dalam membelanjakan uang saku yang di beri orang tuanya, mulai membiasakan diri untuk menyisihkan uang sakunya dan dimasukkan ke dalam celengan mereka yang ada di sekolah. Selain itu pemanfaatan botol bekas juga dapat mengurangi sampah an-organik yang ada di sekitar dan memberikan pengetahuan bahwa sampah tidak hanya dibuang di tempat sampah, tapi sampah juga bisa dimanfaatkan.

\section{B. Saran}

a. Kepada pihak Desa Brangkal diharapkan lebih peduli terhadap pelaksanaan serta pembinaan terhadap kelangsungan dari pengelolaan Bank Sampah.

b. Kepada pengurus inti Bank Sampah agar bisa menerapkan ilmu yang telah diberikan oleh mahasiswa untuk kesempurnaan pembukuan Bank Sampah.

c. Kepada mahasiswa KKN selanjutnya, disarankan sebagai berikut :

1. Agar program sosialisasi pembukuan Bank Sampah ini tetap dilanjutkan.

2. Agar memberikan pelatihan keterampilan yang lebih kreatif lagi. 
d. Untuk kedepannya, diharapkan dari orangtua bisa terus menghimbau kepada anakanaknya untuk giat menabung, giat mengisi celengannya, program isi dan kreasikan celenganmu bisa berlanjut, tidak hanya memanfaatkan botol bekas, bisa menggunakan kardus, kaleng bekas, toples roti dan yang lainnya sebagai alternalive lain untuk dijadikan sebagai elengan dan tidak hanya diwarnai, bisa juga ditempel dengan kain flannel dan dikreasikan.

\section{DAFTAR PUSTAKA}

Ermawati, S., Hidayat, T., Rohmah, I. I. T., Nurdianingsih, F., \& Mujahidin, A. (2017). Daur Ulang Botol Bekas Menjadi Piggy Banks Untuk Mengasah Kreativitas Dan Memotivasi Siswa Untuk Menabung. J-ABDIPAMAS: Jurnal Pengabdian Kepada Masyarakat, 1(1), 92-97.

Lail, J. (2015). Program Sentono Menabung. Asian Journal of Innovation and Entrepreneurship, 4(01), 54-57.

Rahim A.R, Bela ND, Mutmainnah M, Araswati Z. (2019). Sosialisasi Dan Implementasi Pembuatan Krupuk Ikan Bandeng Desa Karanggeneng Kec. Karanggeneng Kab. Lamongan. Jurnal DedikasiMU. Vol 1. No 1. pp 1-10.

Rahim A.R. (2018) Pemanfaatan Limbah Tambak Ikan Untuk Budidaya Cacing Tanah Lumbricus rubellus. Jurnal Perikanan Pantura (JPP). Vol 2. No 1. pp. 1-8.

Rahim A.R. (2018). Application of Seaweed Gracilaria verrucosa Tissue Culture using Different Doses of Vermicompost Fertilizer. Nature Environment and Pollution Technology. Vol 17. pp.661-665.

Rahim A.R., Herawati E.Y., Nursyam H., Hariati AM. (2016). Combination of Vermicompost Fertilizer, Carbon, Nitrogen and Phosphorus on Cell Characteristics, Growth and Quality of Agar Seaweed Gracilaria verrucosa. Nature Environment \& Pollution Technology. Volume 15, No. 4.

Rahim A.R., Ruhumuddin S, Rosmarlinasiah. (2019). Productivity Improvement of Milkfish and Seaweed Polyculture using Vermicomposting Fertilizer from Sources of Waste. International Journal of Recent Technology and Engineering. Volume-8 Issue-3. pp 1377-1381. 
DedikasiMU (Journal of Community Service)

Volume 2, Nomor 1, Maret 2020

Sujiyanto. (2016). Analisis Pengelolaan Sampah di Bank Sampah Malang. Jurnal Ilmu Sosial dan Ilmu Politik. Vol 3, No. 3/April.

Utami, Eka. (2013). Buku Panduan Sistem Bank Sampah dan 10 Kisah Sukses. Jakarta : Yayasan Unilever Indonesia. 